\title{
The Economic Impact of the Covid-19 Pandemic on SMEs in Selected Sub - Saharan African Economies: An Empirical Approach
}

Dr. Ndah Grimbald (Corresponding author)

ICT University, Cameroon

E-mail: ndah.grimbald@ictuniversity.org

Abdallah Ziraba

ICT University, Cameroon

E-mail: abdallah.ziraba@ictuniversity.org

Martha Abeja Ekure

Makerere University Business School (MUBS), Uganda

E-mail:mabeja@mubs.ac

Henry Jong Ketuma

ICT University, Cameroon

E-mail: henryketuma@gmail.com

Received: May 5, 2021 Accepted: June 20, $2021 \quad$ Published: July 10, 2021

doi:10.5296/ber.v11i3.18597ＵRL: https://doi.org/10.5296/ber.v11i3.18597

\begin{abstract}
The Covid-19 outbreak is having substantial economic effects and wreaking havoc on sub-Saharan Africa. The pandemic has unleashed a unique combination of shocks to global commodity markets, disrupting the global supply chain and impacting supply and demand simultaneously. SMEs in lower income countries and particularly in sub-Sahara Africa are bearing the brunt of the economic hardship brought about by Covid-19. To this effect, the
\end{abstract}


purpose of this study is to determine the economic impact the Covid-19 outbreak has on small and medium size (SMEs) enterprises across selected sub-Sahara African economies using an empirical approach to analysis. The phenomenon under study is objectively determined and the source of acceptable knowledge is positivism epistemology. The research approach is a deductive one and the axiological underpinning is value-free. The research paradigm is quantitative method of analysis. A sample of 500 participants from four focus groups namely the Transport sector; Hotels bars \& restaurants; retail stores; \& tourism sector were randomly selected in Cameroon, Uganda, Nigeria and Zimbabwe. Secondary data was also sourced from the IMF, World Bank, OECD, and AU. Four causal relationships were hypothesized and the findings revealed that financial risks, poor economic performance of SMEs, loss of jobs and rising unemployment have a significant positive impact on the survival of SMEs in sub-Sahara Africa. The main impact of the Covid-19 pandemic will depend on its severity and duration but the consequences are likely to be long lasting.

Keywords: Covid-19, Small and medium size enterprises (SMEs), Sub-Sahara Africa (SSA)

\section{Introduction}

The Coronavirus Disease 2019 (COVID-19) is a respiratory illness triggered by a novel coronavirus called severe acute respiratory syndrome coronavirus 2 (SARS-CoV-2) that was first detected in December 2019 in Wuhan city in the Hubei province of China (Evans, 2020) as cited by (Brüssow, 2020; Fauci, Lane \& Redfield, 2020; Gentile \& Abenavoli, 2020; Shang, Yang, Rao \& Rao, 2020). The symptoms of Covid-19 range from fever, flu-like symptoms such as headache, coughing, sore throat and fatigue, and shortness of breath. There is scientific evidence that it spreads from one person to another and has airborne transmission characteristics, good hygiene practices and social distancing measures can however prevent infection (Evans, 2020).

The COVID-19 disease was declared a pandemic by the World Health Organization (WHO) on 11 March 2020, and has become a global emergency, given its impact on the entire world population and the economy. According to several models and projections of the International Monetary Fund (IMF), it is predicted that world economic growth could fall by $0.5 \%$ for the year 2020. Many other sources are likewise forecasting a drop in world economic growth as a result of the direct and indirect effects of the COVID-19 pandemic. It is predicted that the world economy may likely enter into a recession in the first half of 2020 due to the direct and indirect effects of the crisis such as shocks in supply and demand, commodity slump and the fall in tourism arrivals (African Union, 2020). However, as the Covid-19 pandemic is slowly progressing in Africa, studies by international organizations are addressing the economic impact in the African continent as a whole. Africa has not yet obtained an immunization solution of Covid-19. According to Africa Centre's for Disease Control (CDC), the spread of the virus has reached 55 African Union Member States with 4,508,664+ cases; 120,219 deaths and 23,095 recoveries as of April 2021. This dangerous and rising trend is showing no signs of slowing down in Africa, because of its openness to international trade and immigration. Many African households depend on very small businesses for survival and generate their survival income on a daily basis; savings in such household is a luxury. In 
Sub-Saharan Africa (SSA), the SME sector accounts for more than $90 \%$ of all firms. Between $70 \%$ and $80 \%$ of SMEs are micro-firms or very small firms. They are the main source of jobs and income for Africans, after subsistence farming (Ndah \& Nchise, 2019). Lockdown and confinement for a long period of time in Africa will lead to devastating economic and social conditions since most African families and households depend on their daily petty businesses for survival, and therefore cannot afford the luxury of living under confinement without work.

The purpose of this paper is to determine the economic impact the Covid-19 outbreak has on small and medium size (SMEs) enterprises across selected sub-Saharan African economies. Small and medium size enterprises shall be the hardest hit in economic terms in sub-Sahara Africa.

\section{Empirical Literature Survey}

\subsection{COVID-19 in Developing African Economies}

The Covid-19 pandemic continues to take its toll on the African continent; while the continent as a whole still accounts for relatively few deaths from the disease, the numbers are rising with more than 4,508,664 cases and 120,219 deaths by 29 April 2021. As countries scramble to contain the virus and are affected by the efforts of other countries to contain the virus, the economic impact continues to grow as many African countries are locking down meaning that economic activities are either totally shut down or partially shut down. According to World Bank records, the 2020 growth for the continent before the crisis was at $3.9 \%$ and when the Covid-19 outbreak occurred, the growth dropped to 0.4\% (Evans, 2020). The effects of Covid-19 were first realised in China and this will have a great impact on China's global trade for several months. Given the fact that Africa's biggest trading partner is China, Africa is already suffering from the effects of Covid-19. Africa experienced a fall in income from commodity exports due to the fact that China shut down its manufacturing Centre and closed its ports. Importers in China resorted to the cancellation of orders due to the closures of port and as a result of fall in consumption in China; most African traders are now obliged to offload products at a discounted rate elsewhere (Mckenzie, 2020).

Zimbabwe entered a COVID-19 lockdown following other African countries that had done so in an attempt to avoid masses getting infected as a result of populated areas. Reports indicate that as oppose to South Africa where many people disregarded government instructions to stay indoors with some even clashing with the forces of law and order, Zimbabweans mostly remain indoors. Streets in Central Harare were deserted. Also, government offices, businesses and banks were on shutdown. This involved both small and medium size enterprises that will equally face the negative consequences of this lock down.

Sub-Saharan Africa is expected to suffer from an economic backlash due to the Covid-19 pandemic. The IMF projected a recession of $1.8 \%$ across the Sub-Saharan region as a whole, the first since 1991, compared with its past prediction of 3.5\% growth in the April edition of its Regional Economic Outlook for Sub-Saharan Africa (Fletcher, 2020). Like all predictions before, this dire situation should be treated with utmost caution. The economic fallout will 


\section{Macrothink}

Business and Economic Research

ISSN 2162-4860

2021, Vol. 11, No. 3

depend on the length and extent of the outbreak, not only in Africa, but among its trading partners.

Nevertheless, economies that depend a lot on single export-orientated industries will suffer the most. Island countries such as Cabo Verde, Mauritius, Seychelles and São Tomé and Príncipe are expected to suffer from contractions in GDP of between $4 \%$ and $10.8 \%$, an average drop of $10.8 \%$ points from their pre-Covid19 pandemic forecasts due to an effective freeze on global tourism. The region's oil exporters notably Angola, Cameroon, Chad, Congo (Brazzaville), Equatorial Guinea, Gabon, Nigeria and South Sudan will be badly hit by the fall in oil prices that are largely due to the disruption in demand caused by COVID-19. The economies of southern Africa that are mainly characterized by mining will also struggle. The economies of Botswana, Congo (DRC), Zimbabwe and Zambia all rely on primary mineral products for more than $60 \%$ of export revenues and all are predicted to shrink by more than $2 \%$ (IMF, 2020). Also, the drastic fall in the prices of commodities as a result of the Covid-19 pandemic will undoubtedly have devastating consequences in sub-Saharan African economies. (See Figure1 below on the impact of the Covid-19 outbreak on commodity prices and Chinese oil stocks sourced from Bloomberg and the IMF).
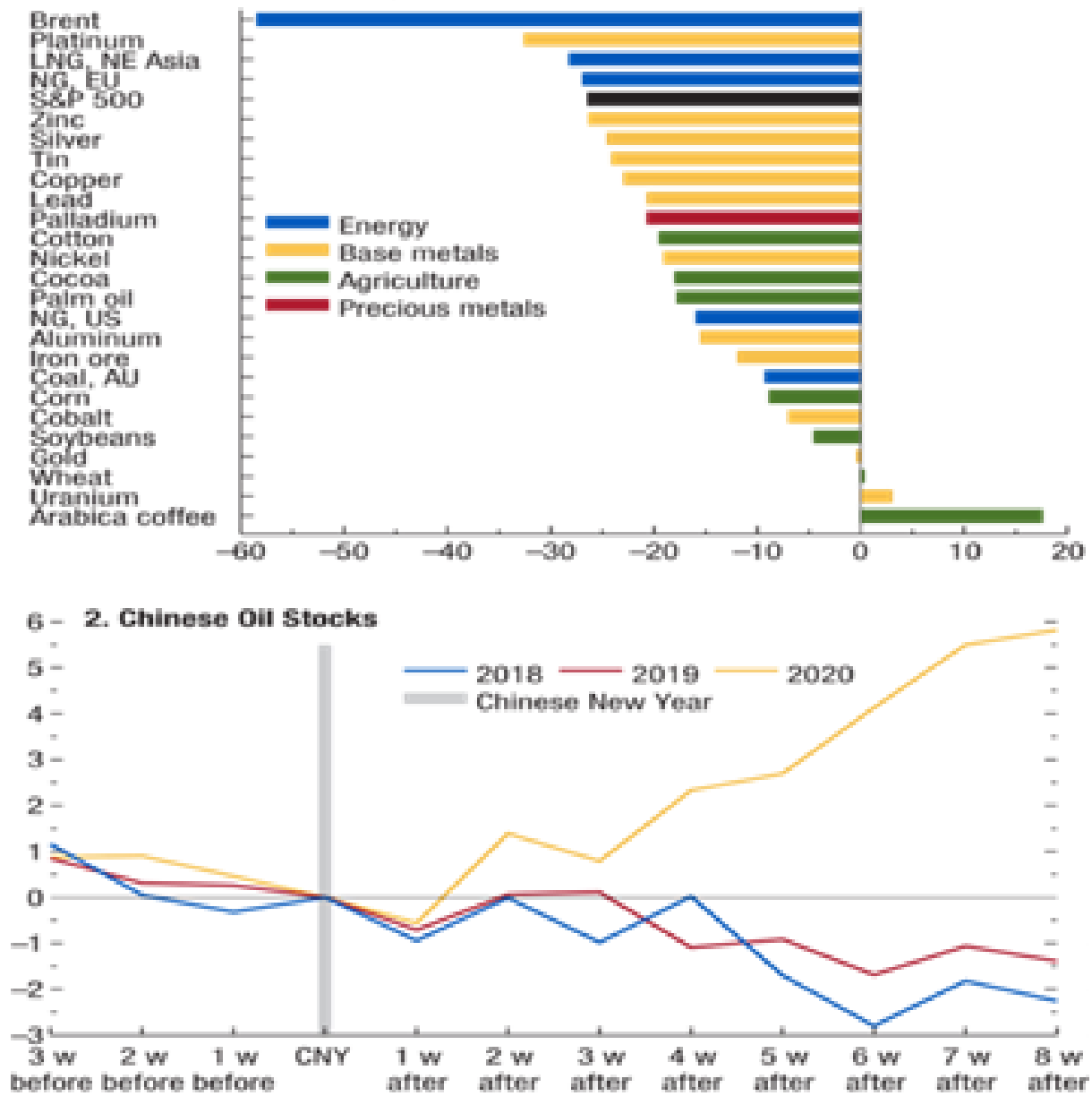

Figure 1. Impact of the Covid-19 Outbreak on Commodity Prices

Source: Bloomberg and IMF Staff Calculation, 2020 
Nonetheless, some countries will prove more resilient to the crisis. In West Africa for example, Guinea, Senegal and Ivory Coast are all projected to experience GDP growth of more than $2.7 \%$ in 2020. In East Africa, Rwanda, Ethiopia and Uganda are expected to grow above 3.2\% growth. These figures represent a drop of 3.8\% points from past's growth estimates. Although this represents an economic hit, it is significantly less than the $5.2 \%$ point drop for sub-Saharan Africa as a whole or the $8 \%$ point drop for the world's advanced economies.

\subsection{COVID-19: What is at Stake for SMEs in Africa?}

SMEs are very important in pushing forward economic growth in Africa, representing about $90 \%$ of all businesses in these economies. With almost every activity grounded due to the Covid -19 pandemic, the SME sector is expected to suffer severely. Since global economic growth is a key driver of commodity prices, local prices have been driven down by the virus's global impact. The uncertainty hovering over local markets in Africa due to the devastating impact of the Covid-19 pandemic is expected to result to increased risk aversion from investors who are waiting to see its potential impact on Africa as a whole. On a positive note, a short term fall in stock prices always open up opportunities for prudent investors including those in SMEs (Mckenzie, 2020).

The health sector in most countries around the world has felt the weight of the economic impact caused by the COVID-19 pandemic. In the case of Sub-Saharan Africa, limited access to sanitation facilities and safe sources of drinking water, weak health systems, urban crowding, the large informal economy, and weak policies may cause serious challenges African governments in an attempt to the lives and livelihoods of their citizens amid the outbreak of the COVID-19 pandemic (World Bank, 2020).

In general, the main channels of transmission of COVID-19 on economic activity in Sub-Saharan Africa include the following: disruptions in commerce and supply chain are the first channels of transmission. Slowing growth in advanced countries including China will have a negative impact on the demand for goods exported from Sub-Saharan African. It will drastically lead to a reduction in the international price of commodities exported by countries of this region especially mineral ores, oil and metals. It will also affect countries with strong participation in value chain. The latter applies to countries with high participation in agribusiness activities (Ethiopia and Kenya), manufacturing goods (Tanzania), auto industry (South Africa), and mineral exporters that are part of the value chain in electronics (the Democratic Republic of Congo and Zambia). Disruptions to GVCs might in turn exacerbate the plunge in oil prices as demand from China declines (World Bank, 2020). The second broad channel of transmission is foreign financing flows into Sub-Saharan African countries. Lower foreign direct investment (FDI) inflows may affect more adversely extractive sectors (energy and mining sectors) and, to a lesser extent, manufacturing activity. As access to financing flows from China and capital markets become more restricted, infrastructure investments will also be severely affected. In the context of these investments, preparation and implementation challenges - along with the reduced financing-may delay the delivery of projects targeting infrastructural development such as roads, energy projects, ports and 
airports. Aid to the region will be seriously affected because as traditional donors like the Europe and the US are most affected by the COVID-19 pandemic and they will certainly use their resources to support segments of their population that are most affected by the economic implications of the virus. The ravaging effects of COVID-19 and falling commodity prices in particular oil could trigger capital flight from Africa especially in countries such as Ghana, Nigeria, and South Africa where investments flow out and where investors bought local currency securities. In addition to the above, the reduced rate in travels is likely to have devasting consequences in the tourism sectors in Sub-Saharan Africa. Countries such as Botswana, Kenya, Mauritius, and South Africa, among others with greater dependence on tourism revenues will be badly affected. The health sector or channel is the third main channel of transmission and the fourth channel include disequilibrium caused by measures of containment and mitigation imposed by sub-Saharan African governments and the response of the citizens. Several problems affect the measures of mitigation as well as the effectiveness of containment in the fight against the spread of COVID-19 across the region.

These problems include poor access to safe and clean drinking water, deplorable sanitation facilities, dilapidated health care systems and large and densely-populated urban informal settlements. Nevertheless, the degree of the COVID-19 impact on the region will also depend on the reaction of the populations within African countries, the rate of spread of the disease, and the policy response measures. This could result to a reduction in labour market participation, lower human capital accumulation, and the underutilization of capital as well as the effects of long-term productivity.

\subsection{Growth Outlook in the Region \& Implications for the Economy and SMEs}

Real GDP in sub-Saharan Africa is estimated to shrink by $-1.6 \%$ in 2020 according to the IMF Regional economic outlook for sub-Sahara Africa in April 2020, the lowest level of growth on record (IMF, 2020). This represents about 5.2\% lower than forecasted in the October 2019 Regional Economic Outlook for Sub-Saharan Africa. This drastic downward revision is due largely to the fallout from the spread of COVID-19 as well as a sharp fall and lower-than-expected commodity prices on which the survival of most SMEs largely depends on. Also, other causes such as prolonged structural restrictions (South Africa), policy adjustment (Ethiopia), and climate and other fundamental factors (such as the locust invasion in Eastern Africa) have also contributed to the downward revisions. The economic consequences due to the Covid-19 pandemic and low commodity prices are expected to be most severe in less diversified economies. Growth in oil exporter economies is projected to decline from $1.8 \%$ in 2019 to $-2.8 \%$ in2020 (a downward revision of $5.3 \%$ points from the October 2019 Regional Economic Outlook for Sub-Saharan Africa). In Nigeria, the largest economy in the region, GDP is expected to contract by $3.4 \%$, mainly reflecting the large drop in oil prices and the impact of containment and mitigation measures on economic activity (IMF, 2020).

These bleak figures and statistical indicators from the April edition of the IMF economic outlook for Sub-Sahara Africa will severely impact the SMEs and business in general in the region. Already, prices of basic commodities and food items such as fish, cooking oil etc. and 


\section{Macrothink}

Business and Economic Research ISSN 2162-4860 2021, Vol. 11, No. 3

transport prices are rising at an alarming rate due to the economic hardship being experienced in the economies of these countries. For example, in Cameroon, the ministry of commerce has reviewed the prices of basic commodities and food items twice. Majority of SMEs in the export-import domain in the region are finding it difficult to maintain supply and boost sales because of disruptions in the global supply chain thereby causing temporary closures and even complete shutdowns in some cases. Many others can no longer maintain their staff size, pay bills or extend their loans with banks particularly in the transport, tourism and Hotel sectors. Unemployment is rising, investment levels are dwindling and the GDP in most of the countries in the region is expected to drop sharply due to the economic fallouts of the spread of Covid-19.

According to data gathered from the IMF World Economic Outlook report for April 2020, global commodity markets developments will further aggravate the economic situation of most developing economies particularly sub-Saharan Africa. This is because a sharp fall in prices of commodities like oil, metals, and cocoa, coffee and food items in general in the world market is expected in the months ahead. Since most African economies are export reliant on commodities such as oil, cocoa, coffee \& metals, this sharp fall in commodity prices (see figure 2 on commodity market developments sourced from the IMF data portal) will severely impact the already fragile economies of sub-Sahara Africa.

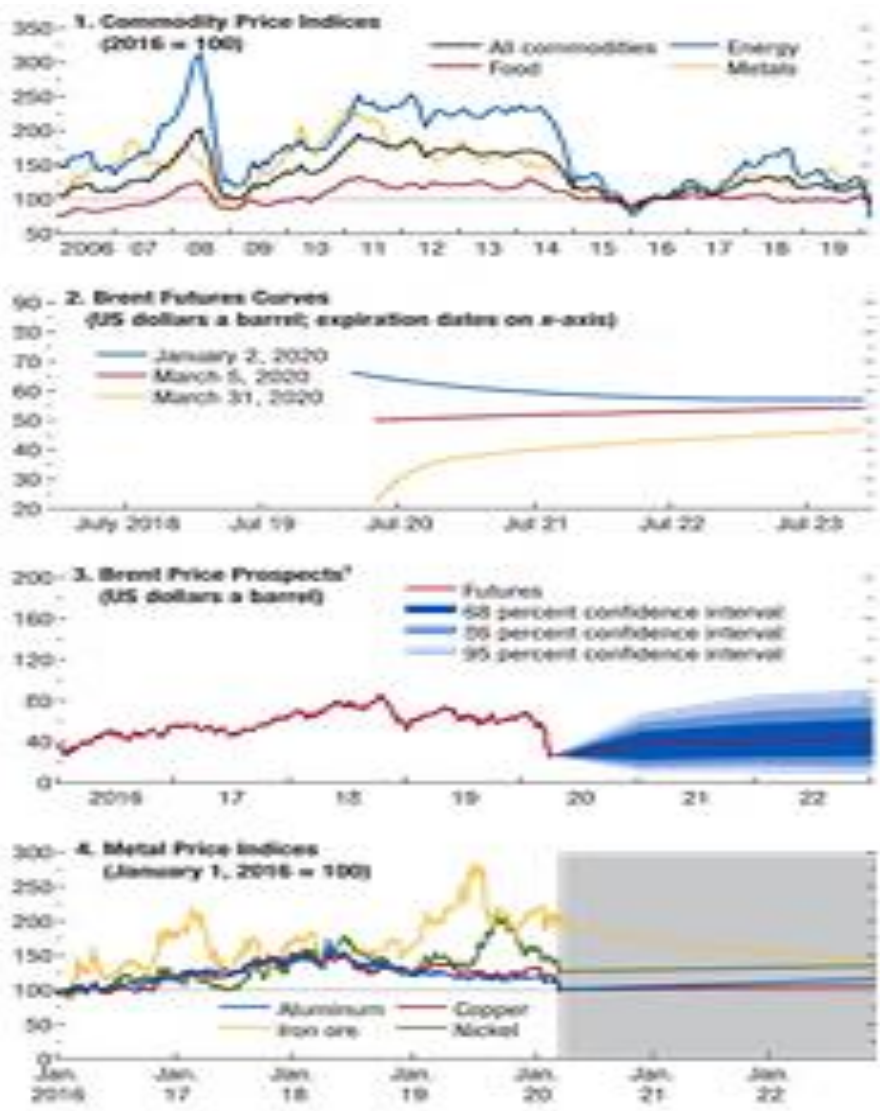

Figure 2. Commodity Market Developments

Source: IMF Data Portal, 2020 
2.3.1 Portfolio Theory (PT) in Decision Making and It's Applicability by Owners of SMEs in Africa

The Portfolio Theory (PT) theory was pioneered by Harry Markowitz in 1952 and is sometimes referred to as the Modern Portfolio Theory (MPT). The Modern portfolio theory (MPT) is an investment theory which attempts to explain how investors can maximize return and minimize risk. It's mainly used to help manage investments especially in the areas of returns and risk. The constructs of this theory are investment, risk and returns.

This theory that is based on two main concepts; the goal of every investor is to maximize return for any level of risk and that risk can be reduced by diversifying a portfolio through individual or unrelated securities. This theory is also based on two assumptions; that investors act in a rational way and adopt behaviour of profit maximisation with a given level of money or income and that investors have access to complete and correct information on the risk and returns levels. The Portfolio theory further describes how investors should make rational choices when they take their decisions based solely on expected return (the mean or average return) and volatility (standard deviation) of stocks. Each investor chooses a portfolio from the efficient frontier based on the risk tolerance level.

Critiques of this theory however believe that Investors are very concerned by downside volatility, but how many object when their portfolio moves up? Volatility is a measure that views an increase in prices of stocks as equally bad as a decrease in stock prices. Critiques also point out to inflation and its negative impact it has on the economy including non-growth assets. Also, stocks traded on the basis of speculation and which are highly volatile do not fit into this category of investments because they do not lead to higher returns compared to a diversified investments (Morien, 2020).

As it is now, many entrepreneurs of SMEs in sub-Sahara Africa are confronted with the choice to continue with their business activities in defiance of restrictive measures put in place by their respective governments or to respect those measures at the economic detriment of their businesses. For example, in Uganda, government is enforcing strict restrictive and confinement measures to limit movement and the opening of businesses while in Cameroon, the government recently announced that businesses could open and the transport sector was free to operate at near - full capacity with the exception of schools till the 01 June 2020. In the absence of a well-coordinated regional response to the Covid-19 pandemic, the region is bound to suffer unprecedented losses in several sectors of the economy as highlighted by the International Monetary Fund (IMF) in its recent regional economic outlook.

Nonetheless, there are many SMEs and institutions in the SSA region that are diversifying their investments and business activities. This is applicable particularly to the educational sector in which most private higher learning institutions have resorted to online teaching and trainings. In addition, SMEs have devised new ways of doing business such as the increasing use of e-commerce and e-banking by banks and financial institutions. Many textile factories are now producing local made masks and many factory warehouses are now serving as temporary hospitals for Covid-19 patients and facilities for health workers. 


\subsubsection{Hypotheses Statement}

Based on the observations mentioned before and the portfolio theory developed by Harry Markowitz mentioned above, the following hypotheses were developed.

H1 : Increased financial risks due to the Covid-19 Pandemic has a significant impact on the survival of SMEs in Sub-Sahara Africa

H2 : Business diversification due to the Covid-19 pandemic has a significant impact on the survival of SMEs in Sub-Sahara Africa

H3 : Loss of jobs and rising unemployment due to the Covid-19 pandemic has a significant impact on the survival of SMEs in Sub-Sahara Africa

H4: The weak economic performance of SMEs due to the Covid-19 pandemic has a significant impact on the survival of SMEs in Sub-Sahara Africa

\section{Methodology}

The reality under study is the economic and social distress caused by the Covid-19 pandemic worldwide with special focus on the survival of SMEs in developing economies. The phenomenon under study is objectively ascertained and the source of acceptable knowledge is positivism epistemology (Akosso, Isoh \& Ndah, 2020). The research approach is deductive and the axiological underpinning is value-free. The causal research design is quantitative method of analysis.. This is because quantitative research is often used to question relationships between variables yielding results that are predictive, explanatory, or confirmatory (Williams, 2011). It aims to produce generalized findings in the form of theories and formulae, and so is sometimes associated with positivistic and deductive studies (Bryman, 2012). The researchers sought to establish a relationship between the Covid-19 pandemic and the economic performance of SMEs in developing economies. Data are quantitatively analysed using Statistical inferences and modeling with the use of statistical software's like SPSS and AMOS. The study applied simple random probability sampling, selecting the sample randomly from the sampling frame using random numbers obtained from tables or generated by a computer (Saunders, Lewis \& Thornhill, 2009). A sample of 500 participants from four focus groups (Transport sector; Hotels, bars \& restaurants; retail stores; \& tourism) constituted by business owners, individual entrepreneurs, and executives of business firms were randomly selected in Cameroon, Uganda, Nigeria and Zimbabwe. Research questions were administered with the use of questionnaires because it has the ability to harness data from a large sample that may be geographically dispersed, and provides broad statistical analysis options (Zikmund, 2003). Well-structured questionnaires were used in this study to provide a hypothetical response of 500 respondents on SPSS worksheet using a 5 Likert scale (SA-SD) and Mean as the measurement of central tendency.

\section{Data Analysis and Presentation of Results}

Data cleaning and management was done and completed using Exploratory Factor Analysis (EFA). The different modalities for analysis were checked. The Kaiser-Meyer-Olkin measure of sampling adequacy $(\mathrm{KMO}=0.654>0.5)$ and the Bartlett's Test of Sphericity with Approx. 


\section{Macrothink}

Business and Economic Research ISSN 2162-4860 2021, Vol. 11, No. 3

Chi-Square $(X 2=462.896)$, Degree of Freedom $(\mathrm{DF}=120)$ and P-Value $(\operatorname{sig}=0.00<0.05)$ both revealed adequacy of the sample size and the existence of at least 1 significant correlation in the data set. Based on the above, the data was fit for factor analysis.

Table 1. KMO and Bartlett's Test

\begin{tabular}{|l|l|l|}
\hline \multicolumn{2}{|l|}{ Kaiser-Meyer-Olkin Measure of Sampling Adequacy. } & .654 \\
\hline Bartlett's Test of Sphericity & Approx. Chi-Square & 462.896 \\
\cline { 2 - 3 } & Df & 120 \\
\cline { 2 - 3 } & Sig. & .000 \\
\hline
\end{tabular}

Source: SPSS Output

Furthermore, exploratory factor analysis (EFA) was conducted. Four fixed components were rotated using Varimax and the rotated component matrix below showed evidence of appropriate loading of factors for respective components with no cross loading and factor coefficient being less than 0.5 . The extracted and well loaded indicators for each variable then became the retained indicator for the study as shown in the EFA table below:

Table 2. Rotated Component Matrix ${ }^{\mathrm{a}}$

\begin{tabular}{|c|c|c|c|c|}
\hline & Comp & & & \\
\hline & 1 & 2 & 3 & 4 \\
\hline FR1 & & & & .785 \\
\hline FR3 & & & & .727 \\
\hline FR4 & & & & .813 \\
\hline $\mathrm{BC} 1$ & & & .784 & \\
\hline $\mathrm{BC} 2$ & & & .709 & \\
\hline $\mathrm{BC} 3$ & & & .845 & \\
\hline JE1 & & .779 & & \\
\hline JE3 & & .795 & & \\
\hline JE4 & & .734 & & \\
\hline EP1 & .755 & & & \\
\hline EP3 & .905 & & & \\
\hline EP4 & .805 & & & \\
\hline $\begin{array}{l}\text { Extra } \\
\text { Rotat }\end{array}$ & $\begin{array}{l}\text { Metho } \\
\text { lethod }\end{array}$ & $\begin{array}{l}\text { ncipa } \\
\operatorname{nax} y\end{array}$ & $\begin{array}{l}\text { npone } \\
\text { Kaiser }\end{array}$ & $\begin{array}{l}\text { alysis. } \\
\text { talization. }\end{array}$ \\
\hline a. Ro & conve & n 5 it & & \\
\hline
\end{tabular}

Source: SPSS Output

\subsection{Validity and Reliability Tests}

All retained indicators and constructs were tested for Construct Validity (CV) and composite 
reliability. The acceptable threshold is when Average Variance Explained (AVE > 0.5) and reliability $(\mathrm{CR}>0.7)$ as shown below:

Table 3. Construct Validity and Reliability

\begin{tabular}{|c|c|c|c|c|c|}
\hline Constructs & $\begin{array}{l}\text { Indicat } \\
\text { ors }\end{array}$ & $\begin{array}{l}\text { Factor } \\
\text { Loadings }\end{array}$ & $\begin{array}{l}\text { Factor Loadings } \\
\text { Squared }\end{array}$ & Validity & Reliability \\
\hline \multirow{3}{*}{$\begin{array}{l}\text { Financial Risks } \\
\text { Effects }\end{array}$} & FR1 & 0.785 & 0.616225 & \multirow{3}{*}{$\begin{array}{l}\mathrm{AVE}=0.60 \\
>0.50\end{array}$} & \multirow{3}{*}{$\begin{array}{l}\mathrm{CR}=0.82 \\
>0.7\end{array}$} \\
\hline & FR2 & 0.727 & 0.528529 & & \\
\hline & FR4 & 0.813 & 0.660969 & & \\
\hline \multirow{3}{*}{$\begin{array}{l}\text { Business } \\
\text { Diversification }\end{array}$} & $\mathrm{BC} 2$ & 0.784 & 0.614656 & \multirow{3}{*}{$\begin{array}{l}\mathrm{AVE}=0.61 \\
>0.50\end{array}$} & \multirow{3}{*}{$\begin{array}{l}\mathrm{CR}=0.82 \\
>0.7\end{array}$} \\
\hline & $\mathrm{BC} 3$ & 0.709 & 0.502681 & & \\
\hline & $\mathrm{BC} 4$ & 0.845 & 0.714025 & & \\
\hline \multirow{3}{*}{$\begin{array}{l}\text { Jobs and } \\
\text { Employment }\end{array}$} & JE1 & 0.779 & 0.606841 & \multirow{3}{*}{$\begin{array}{l}\mathrm{AVE}=0.59 \\
>0.50\end{array}$} & \multirow{3}{*}{$\begin{array}{l}\mathrm{CR}=0.81 \\
>0.7\end{array}$} \\
\hline & JE2 & 0.795 & 0.632025 & & \\
\hline & JE3 & 0.734 & 0.538756 & & \\
\hline \multirow{3}{*}{$\begin{array}{l}\text { Economic } \\
\text { Performance of SMEs }\end{array}$} & EP1 & 0.755 & 0.570025 & \multirow{3}{*}{$\begin{array}{l}\mathrm{AVE}=0.68 \\
>0.50\end{array}$} & \multirow{3}{*}{$\begin{array}{l}\mathrm{CR}=0.86 \\
>0.7\end{array}$} \\
\hline & $\mathrm{EP} 2$ & 0.905 & 0.819025 & & \\
\hline & EP3 & 0.805 & 0.648025 & & \\
\hline
\end{tabular}

Source: SPSS Output and Excel Calculations

Furthermore, Confirmatory Factor Analysis (CFA) was completed based on: GFI, CFI, IFI, TLI, RMSEA, SRMR and the Chi-Square goodness of fit parameters. All observed regression paths in the model as shown below are statistically significant:

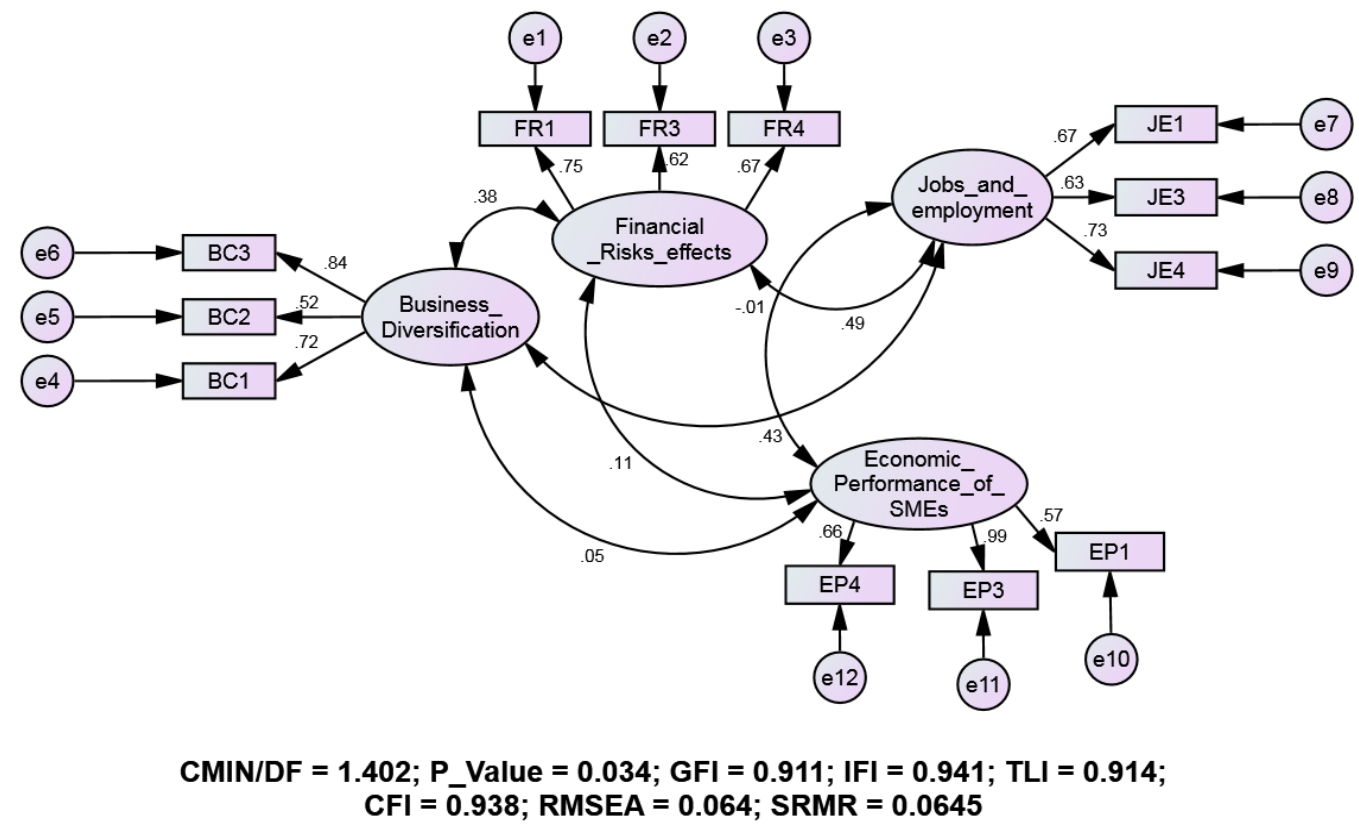

Figure 3. Confirmatory Factor Analysis 
Again, further analysis using the Structural Equation Model (SEM) was conducted in order to test the hypothesis developed in this study. The diagram below shows the SEM model.

\subsection{Structural Equation Model (SEM) and Specifications}

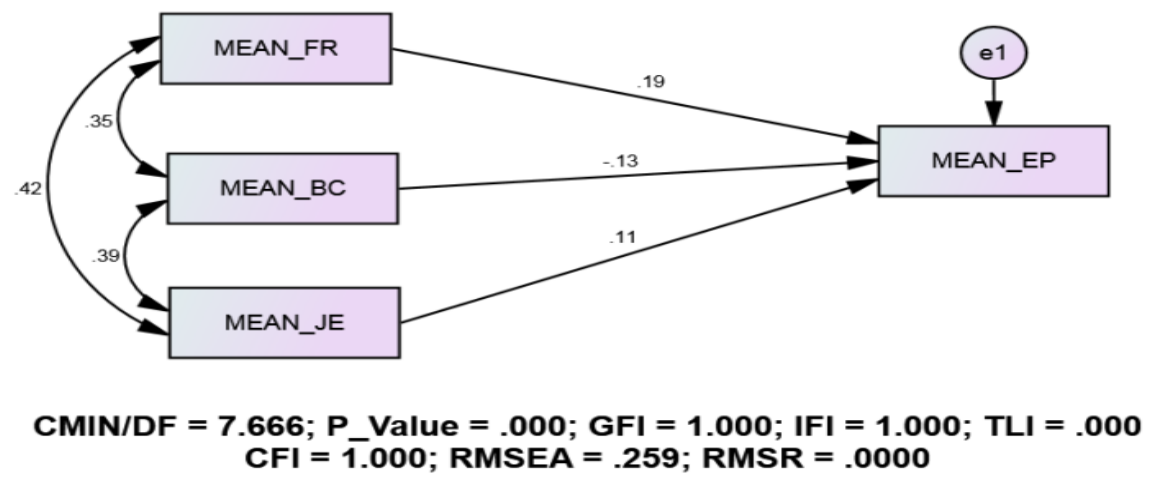

Figure 4. Structural Equation Model

However, based on the structural equation model figure above, the regression paths failed to meet the statistical significance requirements to test the hypothesis. Nonetheless, path analysis was used to test the hypothesis as presented in the output results below:

Table 4. Regression Weights: (Group number 1 - Default model)

\begin{tabular}{|l|l|l|l|l|l|l|l|}
\hline & & & Estimate & S.E. & C.R. & P & Label \\
\hline FR1 & $<---$ & Financial_Risks_effects & 1.000 & & & & \\
\hline FR3 & $<---$ & Financial_Risks_effects & .776 & .164 & 4.731 & $* * *$ & par_1 \\
\hline FR4 & $<---$ & Financial_Risks_effects & .923 & .189 & 4.885 & $* * *$ & par_2 \\
\hline BC1 & $<---$ & Business_Diversification & 1.000 & & & & \\
\hline BC2 & $<---$ & Business_Diversification & .737 & .164 & 4.491 & $* * *$ & par_3 \\
\hline BC3 & $<---$ & Business_Diversification & 1.238 & .235 & 5.277 & $* * *$ & par_4 \\
\hline JE1 & $<---$ & Jobs_and_employment & 1.000 & & & & \\
\hline JE3 & $<---$ & Jobs_and_employment & .910 & .193 & 4.706 & $* * *$ & par_5 \\
\hline JE4 & $<---$ & Jobs_and_employment & 1.214 & .247 & 4.926 & $* * *$ & par_6 \\
\hline EP1 & $<---$ & Economic_Performance_of_SMEs & 1.000 & & & & \\
\hline EP3 & $<---$ & Economic_Performance_of_SMEs & 1.597 & .353 & 4.519 & $* * *$ & par_7 \\
\hline EP4 & $<---$ & Economic_Performance_of_SMEs & 1.090 & .205 & 5.309 & $* * *$ & par_8 \\
\hline
\end{tabular}

Source: SPSS Output

The model in table 4 above reveals that the various constructs i.e. Financial risks effects, business diversification, loss of jobs and employment and poor economic performance of SMEs have a positive statistical significant impact on the survival of SMEs in sub-Saharan Africa based on primary data collected in some selected countries in the region (Cameroon, Uganda, Nigeria \& Zimbabwe). This result also backs the empirical evidence and secondary 
data from the IMF, World Bank, African Union, and OECD\& UN aforementioned in this study relating to the economic impact of the Covid-19 pandemic on the African and global economy.

Table 5. Test of Hypotheses

\begin{tabular}{|c|c|c|c|}
\hline Hypotheses & $\begin{array}{l}\text { P_Value @ } \\
\text { 95\% C.I }\end{array}$ & $\begin{array}{l}\text { Size of } \\
\text { effects }\end{array}$ & $\begin{array}{l}\text { Decision/ } \\
\text { Conclusion }\end{array}$ \\
\hline $\begin{array}{l}\text { H1: Increased financial risks due to the Covid-19 } \\
\text { Pandemic has a significant impact on the survival of } \\
\text { SMEs in Sub-Sahara Africa }\end{array}$ & $\begin{array}{l}* * * \mathrm{P}= \\
0.000<0.5\end{array}$ & 0.189 & $\begin{array}{l}\text { Reject null } \\
\text { hypothesis }\end{array}$ \\
\hline $\begin{array}{l}\text { H2: Business diversification due to the Covid-19 } \\
\text { pandemic has a significant impact on the survival of } \\
\text { SMEs in Sub-Sahara Africa }\end{array}$ & $\begin{array}{l}* * * \mathrm{P} \quad= \\
0.000<0.5\end{array}$ & 0.235 & $\begin{array}{l}\text { Reject null } \\
\text { hypothesis }\end{array}$ \\
\hline $\begin{array}{l}\text { H3: Loss of jobs and rising unemployment due to the } \\
\text { Covid-19 pandemic has a significant impact on the } \\
\text { survival of SMEs in Sub-Sahara Africa }\end{array}$ & $\begin{array}{l}* * * \mathrm{P} \quad= \\
0.000<0.5\end{array}$ & 0.247 & $\begin{array}{l}\text { Reject null } \\
\text { hypothesis }\end{array}$ \\
\hline $\begin{array}{l}\text { H4: The weak economic performance of SMEs due } \\
\text { to the Covid-19 pandemic has a significant impact on } \\
\text { the survival of SMEs in Sub-Sahara Africa }\end{array}$ & $\begin{array}{l}* * * \mathrm{P}= \\
0.000<0.5\end{array}$ & 0.205 & $\begin{array}{l}\text { Reject null } \\
\text { hypothesis }\end{array}$ \\
\hline
\end{tabular}

Although the specifications for goodness fit have been met as shown in figure 4 above, the following were observed as shown in tables 4 and 5 above;

(i) At the $95 \%$ confidence interval (CI) using a sample of 500, there is significant statistical evidence $(\mathrm{r}=0.189$, $* * * \mathrm{P}<0.05)$ to suggest that increased financial risk due to the Covid-19 Pandemic has a significant impact on the survival of SMEs in Sub-Sahara Africa. As a result, we reject the null hypothesis and conclude that increased financial risk due to the Covid-19 Pandemic has a significant impact on the survival of SMEs in Sub-Sahara Africa.

(ii) At the $95 \% \mathrm{CI}$ using a sample of 500, there is significant statistical evidence ( $\mathrm{r}=$ $0.235, * * * \mathrm{P}<0.05)$ to suggest that business diversification due to the Covid-19 pandemic has a significant impact on the survival of SMEs in Sub-Sahara Africa. As a result, the null hypothesis is rejected and it is concluded that business diversification due to the Covid-19 pandemic has a significant impact on the survival of SMEs in Sub-Sahara Africa.

(iii) At the $95 \%$ CI using a sample of 500, there is significant statistical evidence ( $\mathrm{r}=$ $0.247, * * * \mathrm{P}<0.05$ ) to suggest that loss of jobs and rising unemployment due to the Covid-19 pandemic has a significant impact on the survival of SMEs in Sub-Sahara Africa As a result, we reject the null hypothesis and conclude that loss of jobs and rising unemployment due to the Covid-19 pandemic has a significant impact on the survival of SMEs in Sub-Sahara Africa.

(iv) At the $95 \% \mathrm{CI}$ using a sample of 500, there is significant statistical evidence ( $\mathrm{r}=$ $0.205, * * * \mathrm{P}<0.05)$ to suggest that the weak economic performance of SMEs due to the Covid-19 pandemic has a significant impact on the survival of SMEs in 
Sub-Sahara Africa. As a result, we reject the null hypothesis and conclude that the weak economic performance of SMEs due to the Covid-19 pandemic has a significant impact on the survival of SMEs in Sub-Sahara Africa.

\section{Conclusion}

The outbreak of Covid-19 has caused major market disruptions and presented a major shock to commodity markets at a time when prospects for growth in the sub-region were bright. These shocks are worsening an already fragile economic situation of the Sub-Saharan African region. The key objective of this paper which was to determine the economic impact of the Covid-19 outbreak on small and medium size (SMEs) enterprises across sub-Sahara African economies was statistically tested based on four hypotheses. The results of this study show that financial risks affects, business diversification, loss of jobs and employment and poor economic performance of SMEs due to the Covid-19 outbreak in sub-Sahara Africa all have a positive statistical significant impact on the survival of SMEs in the sub region. This can be seen in table 5 where the $\mathrm{P}_{-}$values for the stated hypotheses are all significant within a $95 \%$ confidence interval level. Also, secondary data from African Union, IMF and World Bank sources show that Sub-Saharan Africa will suffer from disastrous social consequences and severe economic hardship due to Covid-19. There is no doubt that the SMEs and very small businesses are going to be among the hardest hit sectors of the economy. African Governments will have to do more to step up mitigation measures and engage in more coordinated regional action in order to limit the spread of the virus, save lives and at the same time prevent economic collapse of their respective economies.

\section{References}

African Union. (2020). Impact of the Coronavirus (COVID-19) on the African Economy.

Akosso, V. N., Isoh, A. V. N., \& Ndah, G. (2020). (2020). Modelling a Sustainable Human Capacity Development Framework of Selected Agro- Industrial Establishments in Cameroon. International Journal of Research in Commerce and Management Studies.

https://doi.org/10.38193/IJRCMS.2020.2027

Bryman, A. (2012). Social research methods (4th ed.). Oxford university press.

Evans. (2020). Socio-economic impacts of novel coronavirus: The policy solutions. BizEcons Quarterly, 3-12.

Fletcher, B. (2020). The economic impact of COVID-19 on sub-Saharan Africa. Delivering Growth and Opportunity.

IMF. (2020). Regional Economic Outlook: Sub Sahara Africa. International Monetary Fund.

IMF. (2020). World Economic Outlook: Global Prospects and Policies. International Monetary Fund.

Mckenzie, B. (2020). The Impact of COVID-19 on Key African Sectors. Capetown: Insight Publications. 
Morien, T. (2020, April 20). Modern Portfolio Theory criticism. [Online] Available: http://www.travismorien.com/FAQ/portfolios/mptcriticism.htm

Ndah \& Nchise. (2019). Assessing the Role of Small and Medium Size Enterprises (SMEs) in Promoting a Sustained, Inclusive and Sustainable Economic Growth of Cameroon. Academic Journal of Current Research.

Saunders, M., Lewis, P., \& Thornhill, A. (2009). Research methods for business students. Prentice Hall.

Williams, C. (2011). Research methods. Journal of Business \& Economics Research (JBER), 5(3). https://doi.org/10.19030/jber.v5i3.2532

World Bank. (2020). Assessing the Economic Impact of Covid-19 and Policy Responses in Sub-Saharan Africa. Africa's Pulse Report, 21.

Zikmund, W. (2003). Business Research Methods (7th Ed.). Thomson/ South-Western.

\section{Copyright Disclaimer}

Copyright for this article is retained by the author(s), with first publication rights granted to the journal.

This is an open-access article distributed under the terms and conditions of the Creative Commons Attribution license (http://creativecommons.org/licenses/by/4.0/). 